Article

\title{
The Legitimation of Self-Regulation and Co-Regulation in Corporatist Concepts of Legal Scholars in the Weimar Republic
}

\author{
Peter Collin \\ Max-Planck-Institute for European Legal History, 60323 Frankfurt am Main, Germany; E-Mail: collin@rg.mpg.de
}

Submitted: 29 September 2016 | Accepted: 1 December 2016 | Published: 15 March 2017

\begin{abstract}
Corporatist regulation has a hybrid structure in that it covers state regulation, regulated self-regulation as well as privatepublic co-regulation. Notably diverging from the standard mode of state regulation, such arrangements required a higher degree of legitimation. Corporatist concepts flourished in the Weimar Republic. This paper deals with three legal scholars' considerations regarding how to legitimize corporatist models, namely Edgar Tatarin-Tarnheyden, Heinrich Herrfahrdt, and Friedrich Glum. Their institutional touchstone was the Imperial Economic Council, as provided for by article 165 of the Weimar Constitution. This article envisioned a multi-level system of economic councils ranging from regional economic councils up to the Imperial Economic Council and involving representatives of all occupational groups in the performance of state tasks. However, only a Provisional Imperial Economic Council, with a restricted consultative remit, was ever actually established. Based on this model, Tatarin-Tarnheyden, Heinrich Herrfahrdt, and Friedrich Glum conceptualized organizational structures aiming at the comprehensive inclusion of non-state actors. They were legitimized primarily with reference to their output; that is, these organizational forms were supposed to enable a more appropriate and efficient realization of public interests. The input-based argument was basically a question of participation, which implies considerable proximity to typical topoi of democratic legitimation. This similarity is perhaps counter-intuitive, given that corporatist concepts are traditionally associated with anti-democratic ideologies due to their anti-parliamentarian slant. The numerous points of convergence between corporatist and democratic thought simultaneously reflect the heterogeneity of democratic reasoning in the Weimar period and the openness for ideas that were sceptical of-or even hostile to-parliamentary democracy and the party-based state.
\end{abstract}

\section{Keywords}

corporatism; public law; self-regulation; Weimar Republic

Issue

This article is part of the issue "Legitimization of Private and Public Regulation: Past and Present", edited by Klaus Dieter Wolf (Peace Research Institute Frankfurt, Germany), Peter Collin (Max Planck Institute for European Legal History, Germany) and Melanie Coni-Zimmer (Peace Research Institute Frankfurt, Germany).

(C) 2017 by the author; licensee Cogitatio (Lisbon, Portugal). This article is licensed under a Creative Commons Attribution 4.0 International License (CC BY).

\section{Introduction}

Who is supposed to make the law? In Germany during the late nineteenth and early twentieth centuries, the answer was clear: the state. This was the prevailing opinion among the scholars of public law (Anschütz, 1914, pp. 152f. $)^{1}$. Until 1918, legal positivism dominated in the field of public law; an etatist model established in the mid-nineteenth century by Carl Friedrich von Gerber and
Paul Laband. According to this model, the state was constructed as a single, unitary entity unable to tolerate any other sovereign beside itself and thus rejecting any alternative legislative authority. This rather superficial finding neither takes into consideration the diverse practice of rule-making nor deviating opinions. Nevertheless, nonstate regulation (especially norm-setting) took place outside the established structures and were always in need of legitimation.

\footnotetext{
${ }^{1}$ One exception was customary law, which, however, had already lost significance by the beginning of the twentieth century.
} 
The aim of this article is to analyse certain concepts connected with societal self-regulation and private-state co-regulation that emerged during the Weimar Republic: corporatist ideas of regulation developed by public law scholars. Which regulatory structures were developed, and how were they legitimized? In order to illustrate the context within which the authors operated at that time, I will begin with a short overview of the nonstate and semi-statal forms of regulation that were already existent at the end of the nineteenth and the early twentieth centuries. Next I will briefly outline the jurisprudential and political models that emerged toward the end of the nineteenth century, and which partially served as a breeding ground for the concepts dealt with here (1.1.). The following section introduces the Imperial Economic Council (incorporated in the Art. 165 of the Weimar Constitution), which served as the organizational starting point for the corporatist concepts (1.2.). The main part of this text is broken into two sections: the first section is dedicated to the presentation of these corporatist concepts (2.). Here, we will pursue questions such as: How should the corresponding structures of regulation be composed? What forms of regulatory competences should the actors possess, and what should their relation to state actors be? The second section deals with the legitimation of these norm-setting structures (3.): Which legitimatory considerations were deemed important (3.1.)? Which criteria for legitimation were put in place (3.2.)? Which sources of legitimation and topoi were applied (3.3.)? Particular attention will be paid to the role of different concepts of democracy as well as the possible connections to national socialist ideology. As a result, the legitimating structures of a regulatory concept will be exposed; a concept which from the contemporary perspective seems alien and hostile towards democracy. Nevertheless, I want to stress that this understanding was an attempt to react to political crisis and new societal differentiations.

\subsection{Traditions of Legal Pluralism and Non-State Norm-Setting Structures in Nineteenth Century Germany}

Starting in the second half of the nineteenth century, a variety of new forms of non-state regulation or regulation only partially embedded in the state structures emerged. Generally speaking, we can distinguish between three different kinds: judicial, administrative, and norm-setting. Judicial forms included for instance permanent commercial arbitration courts, which excluded the competence of state courts, arbitrating bodies responsible for labour and social law staffed with representatives of the involved groups, as well as mediation panels for dealing with conflicting group interests, for instance, between health-insurance providers and doctors or between banks, credit cooperatives, and savings banks. Ad- ministrative forms included for example the supervision of technical facilities by private associations, the management of water resources by water cooperatives, the organization by health insurance providers or the organization of occupational safety by employers' liability insurance associations (Collin, 2016).

However, what attracted the most attention were the norm-setting forms, for they most sharply called into question the state monopoly on regulation. Here, too, we are dealing with a manifold of forms: transport regulation by railway companies; codification of trade practices by chambers of commerce; competition laws between representatives of business conglomerates; cartel statutes; technical standards by engineering associations; and requirements for vocational training by chambers of crafts (Collin, 2015). Non-state normativity was most vivid and obvious in labour law, as Rudischhauser (2016) shows in a recent study. There was no uniform concept of legitimation for all these normsetting forms. Nonetheless, it was the concept of autonomy that had the greatest impact. The concept of autonomy, which states that non-state associations are also allowed to set norms, can be found in publications of legal positivism, too. There, however, the right to autonomy was bestowed by the state. Hence, it was no original right, but rather derived from state sovereignty (Kremer, 2012, p. 28).

The Genossenschaftstheorie (theory of cooperative associations) ${ }^{2}$ also considered autonomy to be a source of law; however, its conception of autonomy was much more state-independent. This theory, which is associated above all with names like Georg Beseler (1843, pp. 182-183), Otto Bähr (1864, pp. 31-32) and-most prominently-Otto von Gierke $(1873,1902)$, tried to derive the existence of independent fields of law from the existence of non-state cooperative associations, which would also imply the existence of a self-contained legislative power. This concept of autonomy established itself in the legal literature, but its persuasiveness and its scope of validity had noticeably eroded starting in the 1870s, as the sway of the cooperative movement waned and the state convincingly claimed its monopoly on lawmaking (Collin, 2014, pp. 165-228; Kremer, 2012, pp. 3-32).

In the nineteenth century, too, corporative state concepts were becoming more influential (Mayer-Tasch, 1971; Meyer, 1997; Nocken, 1981; Ritter, 1998). Essentially, they aimed at the abolition or relativization of a parliament elected by universal suffrage. They wanted to establish a body of representation composed of representatives from various occupational groups. To an extent, they were still oriented towards pre-modern and pre-constitutional conceptions and models. And in this respect, one could certainly characterize them as conservative. Yet, such a characterization cannot sufficiently

\footnotetext{
${ }^{2}$ The difference between cooperative and corporatist in terms of political theory is that the former is mainly concerned with various associations and communities within the state and emphasizes the preservation of their legal capacity. The second concept deals mainly with shaping macro-societal structures. However, there is considerable overlap between the two concepts.
} 
explain the appeal of these concepts exercised. Especially during the second half of the nineteenth century, corporatist ideas were also an attempt to take into account new social differentiations as well as to integrate the working class. To this end, parliamentary-like councils were to be established which were supposed to represent the realities of economic life and which above all had equipped with advisory functions. In practice, however, these ideas never gained traction. Bismarck failed in his attempt to install an economic parliament (Deutscher Volkswirtschaftsrat), at the Imperial level, as a competing model to the Reichstag. Furthermore, the Prussian Volkswirtschaftsrat that Bismarck had initiated was dissolved a few years later, since the Prussian parliament had refused to fund it.

\subsection{The Imperial Economic Council as the Conceptual Starting Point}

In certain sense, these concepts crossed paths again after 1918. Once the monarchy had been overthrown, a new constitution was intended to sort out the changed circumstances. The primary author of the draft constitution was the left-liberal jurist, Hugo Preuß, a student of Otto von Gierke. He only envisioned the draft constitution as a purely parliamentarian system. There was no place for councils or boards other than the parliament (Ritter, 1994, p. 77; Westphal, 1925, p. 51). Yet this concept met with bitter resistance on the part of the workers, who were striving to create a council system based on the Russian model. Demonstrations, strikes, and armed assaults were the result of this opposition. The government reacted by offering an amended draft of the constitution. The article at the centre of this struggle was Art. 34a, which provided for the establishment of workers' councils, especially in the companies, and creation of economic councils in which employees and employers alike were represented (Albrecht, 1970, pp. 91-95; Riedel, 1991, p. 126).

However, even the workers' party, the SPD, was partly sceptical towards the idea of establishing councils. Several leading members were confident that it could achieve the party's goals and push forward its ideas in a parliamentarian system. From a number of different directions, attempts were made to convince the constituent assembly of the viability of the council system concept. The Ministry of Economics used economic considerations to make its point: The councils should be part of a Gemeinwirtschaft (social economy) (Moellendorff, 1919, p. 8; Gesch, 1926, p. 19). These ideas were mainly propagated by the Undersecretary of State at the Ministry of Economics, Wichard von Moellendorff, one of the most important architects of the concept of social economy, who had the Prussian Volkswirtschaftsrat in mind when it came to the creation of an economic council (Glum, 1930b, p. 579). Already before 1918, during the war, he had advocated the establishment of an economic council (Moellendorff, 1916, p. 32). In this case, the economic council was embedded in technocratic approaches based on a planned economy.

Hugo Sinzheimers's line of argumentation turned out to be more persuasive. Sinzheimer was a jurist and SPD deputy in the constituent assembly. He is referred to as one of the "fathers" of labour law, which he considered to be a primary field of application when it came to non-state regulation. Already during the war, he advocated the establishment of economic councils (Sinzheimer, 1916, pp. 198-202). In contrast to Moellendorff, his approach was not technocratic, but-heavily influenced by Gierke-rather emancipatory in its conception: Alongside the domain of the state, there should be a social sphere where the involved parties autonomously establish their own law or at least are involved to a significant extent in the norm-setting process. For this to take place, independent organisational structures were supposed to be established. As a result, a "social parliamentarianism" should be created alongside the "state parliamentarianism", which would primarily be situated within the Imperial Economic Council (Albrecht, 1970, pp. 100103; Völtzer, 1992, pp. 294-297). Sinzheimers's plea was very well received in the constituent assembly. Having recognized corporative state elements in the idea of the Imperial Economic Council, conservative representatives, too, appreciated Sinzheimers's approach (Albrecht, 1970, p. 143; Pohl, 2002, p. 194ff.; Ritter, 1994, p. 98).

The result of the consultations in the National Assembly was Art. 165 of the Weimar Constitution. Art. 165 III-VI provided for the establishment of a central body in which all of the important professional groups were supposed to be represented, and that it was to be consulted regarding all economically and socio-politically relevant draft bills. In addition, the Imperial Economic Council was supposed to have the right to draft bills of its own. Furthermore, this norm provided for the establishment of regional economic councils (Bezirkswirtschaftsräte) with an analog structure. In the end, only the central board, the Provisional Imperial Economic Council (Vorläufiger Reichswirtschaftsrat), was ever erected. The effects of this council were limited in scope (Lilla, 2012; Rehling, 2011, pp. 180-182).

Thus, an incomplete institution had been created, an institution that provided a resonance chamber or space for a variety of partly conflicting approaches: for socialist as well as conservative views, for democratic as well as for anti-democratic ideas, for concepts of self-regulation and corporatist state models. The Imperial Economic Council was the conceptual starting point for the authors discussed in the following sections.

\section{Corporatist Concepts in Public Law}

I will illustrate how the debate itself developed among scholars of public law by looking at the work of three authors: Edgar Tatarin-Tarnheyden, Heinrich Herrfahrdt, and Friedrich Glum. In the literature, quite often just the first two are classified as distinct representatives of 
the corporatist movement among public-law professors (Bohn, 2011; Meinck, 1978; Meyer, 1997; Stolleis, 1999, p. 173). It was only a small group in the state law community to which only Franz Jerusalem could also be included (Jerusalem, 1930, pp. 23-25), though he focused on sociology. ${ }^{3}$ Friedrich Glum, in contrast, is normally not regarded as a member of this group. Still, his conception of the Imperial Economic Council shows many similarities to corporatist models, which demonstrates the openness of such models to non-corporatist elements. In general, the idea was to base comprehensive models of the state on a specific variation of corporatism in which decisionmaking power and influence is located in forums organized around particular occupations.

\subsection{Edgar Tatarin-Tarnheyden}

Of all the public law professors, Edgar Tatarin-Tarnheyden was the one who had developed the most distinct corporatist concept. A Baltic German raised in the Tsarist Empire, he moved to Germany in 1917, completed his habilitation thesis in 1922 and became a professor at the University of Rostock in the same year. ${ }^{4}$ Already in his habilitation (second thesis) his preference for the replacing the parliamentary system with a corporatist system was evident. At the time, however, he saw little chance for this to come to pass and, therefore, satisfied himself with calls for the establishment of a second chamber beside the Reichstag (Tatarin-Tarnheyden, 1922, p. 243). Despite this reticence, he developed an extended corporatist concept in his 1922 book that reappeared in later publications. The Imperial Economic Council was his prototype, and he proposed expanding it in three directions. Firstly, it was to be placed on a foundation of local and regional economic councils (Tatarin-Tarnheyden, 1930, pp. 64-66, 1931, pp. 23-24). Secondly, he intended to broaden its social basis by including further professions, such as white-collar professions and other social groups, like mothers (Tatarin-Tarnheyden, 1922, pp. 237-239). Thirdly, he wanted to expand the Imperial Economic Council's powers to include the authority to enact laws (Tatarin-Tarnheyden, 1930, p. 62, 1931, p. 24).

\subsection{Heinrich Herrfahrdt}

Similarly for Heinrich Herrfahrdt, Privatdozent at the University of Greifswald and extraordinary professor since $1932,{ }^{5}$ art. 165 of the Weimar Constitution was the conceptual point of departure. He also proposed expanding the system of corporatist bodies by placing it on a broader and more functionally differentiated founda- tion (Herrfahrdt, 1921, p. 149). However, in contrast to Tatarin-Tarnheyden, he sought to spare these bodies the dilemma faced by the parliamentary system, namely that questions of substance are secondary to the search for majorities. Therefore, the corporatist bodies should not act by means of voting but through consultation. In order to equip this consulting function with sufficient authority, the corporatist institutions were to be represented in the parliamentary legislative committees by their experts (Herrfahrdt, 1921, pp. 168-170) in order to participate in the regulation of parliamentary processes. This proposal also gained prominence in later publications (Herrfahrdt, 1932, pp. 31-32), as Herrfahrdt shows a more anti-parliamentarian attitude (Meyer, 1997, p. 247f.). However, he expanded it by pleading for stronger corporatist structures at the municipal level as well as for a share of the decision-making power instead of a merely consultative role (Herrfahrdt, 1925, p. 546).

\subsection{Friedrich Glum}

Friedrich Glum fits less comfortably in this group. Firstly, as mentioned above, he is usually not considered a member of the group of corporatist legal scholars. Secondly, his primary focus lied outside of academic research. Nevertheless, he was a legal scholar holding the professorial qualification (Habilitation), and as Director-General of the Kaiser Wilhelm Society (the precursor of the Max Planck Society), he was influential among academics. ${ }^{6}$

Glum was not excluded from the corporatist group without reason. Although his starting point for nonparliamentary regulation was also the Imperial Economic Council, he approached it with a different emphasis, especially in the late 1920s. He explicitly argued against a corporatist system on the basis of occupational representation because he equated this with the hegemony of the economy (Glum, 1929, p. 49, 1930a, pp. 74-75). Despite this, he considered the Imperial Economic Council, which was organized by occupation, to be an appropriate instrument for the realization of his own proposals. Glum employed an argumentative trick to overcome the apparent contradiction: he regarded the Imperial Economic Council not as a body representing the interests of particular occupational groups, but rather as a body representing the overarching economic interests (Glum, 1925, p. 17, 1929, pp. 46, 49). Therefore, Glum refused to consider the Imperial Council in terms of a mere advisory board. Because of its position as a representative of overall interests, so he argued, it would be in a position to set the agenda and not merely serve in an advisory capacity (Glum, 1929, pp. 47-48).

\footnotetext{
${ }^{3}$ Stolleis (1999, p. 173) includes Ernst Rudolf Huber and Hans Gerber. Huber was indeed concerned with corporatist concepts (Norpoth, 1998, p. 79f.; Walkenhaus, 1997, pp. 63-65), though they did not play a central role for him (Jürgens, 2005, p. 126). He was sceptical about their realism and their opposition to the authoritarian conceptions of the state, which he preferred (Huber, 1932, pp. 953-958). Hans Gerber held a similar conception of the state, but he did not go further than a few complementary comments (Gerber, 1932, p. 27). This also applies to Heinrich Triepel, who likewise neglected to develop concepts of his own in this direction (Triepel, 1928, pp. 36-37; see also Gassner, 1999, p. 419).

${ }^{4}$ For biographical information, see Buddrus and Fritzlar (2007, pp. 397-399).

${ }^{5}$ For further biographical information, see Schwinge (1961).

${ }^{6}$ For biographical infomation, see Weisbrod (1995) and Przyrembel (2004).
} 


\section{Legitimation Patterns}

While this account of a handful of corporatist theories is admittedly brief, it nevertheless suffices to raise the question of how they treat the legitimation of non-state regulation and private-state regulation, respectively. The models presented below are especially noteworthy in two ways for how they legitimate. On the one hand, they aimed at enlarging the legitimation basis of state activity. Basing the exercise of public power exclusively on parliamentary principles was seen as inadequate, and the inclusion of non-state organizations was intended to compensate for this deficit.

On the other hand, these concepts legitimize nonstate regulation in the form of public-private coregulation, that is, the partial transfer of regulatory functions to non-state actors. Despite Tatarin-Tarnheyden's references to Gierke, nobody supported regulation without any state involvement.

The following observations are structured around the framework described in the preliminary remarks of this special edition. Accordingly, I deal with legitimation requirements, criteria of legitimacy, as well as with sources of legitimation and legitimation topoi.

\subsection{Legitimation Requirements}

There are different types of legitimation requirements to consider: legal legitimation in the sense of justification through existing higher-ranking norms and legitimation in the sense of de lege ferenda proposals based upon state theoretical considerations. In either instance, the focus was on the Imperial Economic Council. The Imperial Economic Council did not require special legal legitimation, because it was already provided for in the constitution and thus legitimized by a supreme norm. However, this legal legitimation would not suffice if this structure were to be expanded beyond the authority and boundaries defined by the constitution. Taking the Imperial Economic Council as a prototype for further conceptualizations of general patterns of non-state or privatestate regulation required legitimation on the basis of constitutional theory rather than constitutional law, for this was the corporatist project in the proper sense. The crucial point for the corporatist authors was not only staffing state boards with non-state actors, which would have been etatist-centralist corporatism. Rather, their basic idea was a kind of bottom-up corporatism as an encompassing mode of societal self-regulation. Non-state groups should be in charge of their own affairs, and this mode of self-regulation should also be applied to regulatory structures organized by the state. This was, as mentioned above, the common denominator-but with different emphasis.
Tatarin-Tarnheyden started with "internal self-regula-

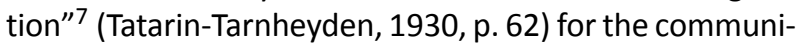
ties on the lowest level and extrapolating this kind of legislation as the primary mode up to the highest level. Similar thinking can be observed in Herrfahrdt's works: “Every group manages its internal affairs autonomously; matters of common interest are to be regulated as much as possible by means of voluntary cooperation" 8 (Herrfahrdt, 1932, p. 24). These conceptions of self-government were ultimately rooted in the thinking of Georg Beseler and Otto von Gierke. In the slightly weaker form of the consultative participation of societal groups, this concept can also be found in Glum's works (Glum, 1925, p. 24). ${ }^{9}$ For all of them, the issue came down to entrusting non-state actors with public authority and this required legitimation.

\subsection{Legitimacy Criteria}

What are the standards for the participation of non-state actors in regulatory activities? The corporatist authors' concepts can be differentiated along the lines of input and output criteria. The input criteria reflect the topos of "participation", which would find broad agreement among these authors. The argument was that representative bodies that allow the persons or groups affected to express their concerns would guarantee greater participation than the parliaments where interests were mediated by political parties interested in the accumulation of political power (Glum, 1920, p. 5, 1925, pp. 9, 23, 1929, p. 32; Herrfahrdt, 1921, pp. 149, 168-170; TatarinTarnheyden, 1922, pp. 241-242, 1931, p. 23).

The second legitimacy criterion, the effective realization of public interests, fits more easily on the output side; however, this single criterion displayed considerable internal variation. According to Tatarin-Tarnheyden, communicating special interests in a corporatist representative body posed no threat, because his new, allencompassing corporatist system would ensure that all particular issues would have an equal voice. Thus, this "ensemble of particular interests" (Tatarin-Tarnheyden, 1922, p. 241) would maximize public interest. Herrfahrdt, by contrast, did not focus on formulating and balancing particular interests, but rather on the integration of expertise from the affected groups into the process of formulating public interests. Effective realization of public interests meant for him primarily the "appropriate" communication of the "true interests of the people", protected from distortions by the party system (Herrfahrdt, 1921, pp. 144-145, 1925, p. 543). Glum also emphasized that corporative representation should be organized such that the struggles among particular interests recede into the background. Instead, communication should be arranged to give prominence to general interests (Glum, 1929, pp. 52-54).

\footnotetext{
7 “Normsetzung für den eigenen Kreis”.

8 "Jede Gruppe verwaltet ihre inneren Angelegenheiten selbst, die gemeinsamen Angelegenheiten werden möglichst im Wege freien Zusammenwirkens bewältigt...".

9 "Heranziehung der Nächstbeteiligten".
} 


\subsection{Sources of Legitimation and Legitimation Topoi}

A central legitimation topos in the concepts described here was "democracy". This is perhaps surprising at first glance, as the authors mentioned here are usually considered anti-democratic.

However, the typology underlying the classification of "democratic" and "anti-democratic" needs revision, because the range of political-conceptual opinions in the Weimar Republic is easily misconstrued. Early research focused almost exclusively on the anti-parliamentarian right-wing, whose program, however diverse it may have been, was summarized under the topos of "antidemocratic thinking" (Sontheimer, 1964). Decisive for this classification was the rejection of the parliamentary or party system by the rightists. Thereby, not only did the early research lose sight of "democratic thinking", but, due to the omission of a comparison of "democratic and "anti-democratic" thinking, it meant that there was a lack of sufficient criteria when it came to the precise reconstruction of the political range of opinions (Schönberger, 2000, p. 156).

Recent research has recognized this problem and has contributed to a more nuanced picture. This change of perspective results, first, from placing "democratic thinking" or, to be more precise, the concepts of political theory attributed to the democratic spectrum, at the centre of current research (Groh, 2010; Gusy, 2000; Klein, 2007). Second, right-wing conceptions of democracy have received more attention (Lobenstein-Reichmann, 2014; Rehling, 2015).

These shifts in perspective have led, firstly, to rejecting a uniform understanding of democracy (Groh, 2014, p. 238). This was, on the one hand, due to the fact that the Weimar Constitution equivocates on this question. It contains parliamentary decision-making mechanisms, extensive authority for the president (Reichspräsident), direct democracy by referendum as well as the participation of corporatist bodies (Kühne, 2000, p. 126). On the other hand, the term "democracy" was used by almost all of the political forces involved, giving it a variety of inflections. What concept of democracy lay behind any utterance is only partly indicated by adjectives such as "true", "real", "social", "socialist", "bourgeois", "German" and "Christian" (Eitz, 2015, p. 110).

Secondly, recent research has shown that current standards are not very helpful in determining what concepts are to be classified as "democratic". Especially those of the modern German constitution (Grundgesetz) are misleading. By today's standards, not only leftist ideas of a soviet republic (Räterepublik) found in the early Weimar Republic, but also the concepts of economic democracy (Naphtali, 1928) developed later in the period would be considered "undemocratic" (Gehlen, 2013, pp. 144-145).

To avoid this pitfall, Gusy proposed using a "historically appropriate, realistic concept of democracy" (Gusy, 2000, p. 637). I seek to follow this counsel by using Gusy's criteria to distinguish "democratic" from "undemocratic" (Gusy, 2000, p. 637):

(1) Democracy implies sovereignty of the people understood as all citizens independent of ethnic or racial criteria;

(2) The people are not imagined as an ideal unity, but as a plural entity whose origin is the individual;

(3) The will of the people is not ideally presupposed and merely revealed via elections and referenda, but rather this will first come into being through such elections and referenda;

(4) Shaping of the will of the people requires a complex organization in which parties and associations play an important role in mediating that will;

(5) Managing the affairs of state is not concentrated in the person of an individual leader, but spread among a multiplicity of leaders.

These criteria reveal not only to what extent public law scholars who are usually considered "confirmed democrats" (for instance, Hugo Preuß, Gerhard Anschütz, Hermann Heller) wavered in their democratic attitude (Groh, 2010, pp. 41, 62, 183; Schönberger, 2000, pp. 165$167)$, they also clarify to what extent the concepts of corporately-minded lawyers overlapped with the democratic spectrum. This point is also emphasized in modern historical research on corporatism (Rehling, 2015, p. 134).

Before subjecting Tatarin-Tarnheyden, Herrfahrdt, and Glum's concepts to the criteria above, a caveat should be mentioned. The premise, shared by all corporatist authors, was the refusal of a democracy based only on, first, a simple headcount principle and, second, on the mediation of the popular will exclusively through political parties. This "quantitative" understanding of democracy was contrasted by a "qualitative" understanding, in which the "true" interests of the people could manifest themselves. Here, too, however, there were a variety of different emphases.

In Tartarin-Tarneyden's concept of an "organic" democracy, small communities at the lowest level were to regulate their own distinct domains, as mentioned above. For higher level legislation, these communities would delegate representatives to "larger units of community work" ("größeren Zellen der Gemeinschaftsarbeit"). Thus, Tatarin-Tarnheyen conceived democratic structures organized as being built from the bottom up (Tatarin-Tarnheyden, 1930, p. 62, 1931, pp. 23-24).

Glum similarly thought in terms of a "true" democracy, even though the organizational design was not as distinct as Tatarin-Tarnheyden's concept. His concept of democracy was also characterized by patterns of selfgovernment. However, it must be said that in the late Weimar period, an elitist understanding of democracy was ascendant that displayed admiration for Mussolini's Italy (Glum, 1930a). Furthermore, he considered the participation of non-state actors and the self-organization of social groups as a mode of integration into the state 
(Glum, 1929, pp. 32-34, 1930a, pp. 16, 129). By using the term "integration", he alluded to Rudolf Smend's much discussed concept of "integration" (Glum, 1929, p. 34). Smend had confined the application of his concept to state mechanisms and political parties without applying it in semi-official contexts (Smend, 1928), ${ }^{10}$ so Glum tried to expand the idea and to thus develop an additional legitimation topos for non-state regulation.

While Herrfahrdt did not present an elaborate concept of democracy as a legitimation topos for corporatist conceptions, he nevertheless also viewed popular government as a basic premise, though excluding the distorting effects of party domination (Herrfahrdt, 1921, pp. 144-145). In his view, popular government develops best in the context of self-government (Herrfahrdt, 1922, 1932 , p. 30). This topos is also evident in the writings of the other authors (Glum, 1925, 1930a, 1931, p. 121; Tatarin-Tarnheyden, 1931, pp. 23-24). Self-government was a positively connoted term across all party boundaries. The principle of self-government had a respected heritage, it promised the immediate participation of the groups concerned, and it seemed to suit the German national character better than a parliamentary democracy.

Hence, it should be noted that, on the one hand, there was opposition to the parliamentary democratic model supported by legal scholars designated as democratic, including Preuß, Anschütz, Thoma, Kelsen, and Heller (Herrfahrdt, 1922, 1932, p. 30). On the other hand, the approaches offered by Tatarin-Tarnheyden, Glum, and Herrfahrdt display elements that conform to the criteria sketched out above:

(1) They all start from the sovereignty of the people. Legitimacy is deduced neither from monarchic divine right nor from any kind of charismatic leadership (Führertum). Furthermore, the concept of the nation is not understood in an ethnic, racial or biological sense. After 1933, TatarinTarnheyden displayed a clearly ethnic-nationalist mindset (Tatarin-Tarnheyden, 1934, p. 32), ${ }^{11}$ but this was not a constituent element of his theory during the Weimar period.

(2) The people are not imagined as an ideal unity but as a plural entity. The elements constituting plurality are, however, not individual citizens, but groups. By positing that group interests should be brought into the social process of determining the popular will, individual citizens, as decision-making subjects, are passed over. The ascription of a status to a certain individual reduced the options to vote positions, parties, or persons not represented in the status group. However, individual interests were not to be completely ignored. The process of reconciling individual or particular group interests was simply shifted to corporate bodies.

(3) The popular will, which consists of particular group interests, is not merely identified but generated in a complex process. This could be carried out in a complex system of corporative bodies, according to TatarinTarnheyden, or in a more consultative setting with parliamentary processes of opinion formation, as in Herrfahrdt's concept. This applies to Glum's approach only to a limited extent, because the processes of opinion formation he refers to, drawing on Smend, serve to "make the community that is to be represented present as a unity" (Glum, 1929, p. 32).

(4) This process of generating the popular will took place in complex organizational structures via interdependent bodies (Tatarin-Tarnheyden) or via the interaction of corporatist consultative bodies and parliamentary decision-making institutions (Herrfahrdt, Glum). Given that they provided for election-or at least delegation-procedures, their conceptions clearly encompassed democratic elements as well as other, in this respect, defective features. ${ }^{12}$

There are important differences to note concerning the decisive role of parties and associations as mediators of interests that democratic theories typically require. To the extent that parties played any role at all in the approaches mentioned, it was a subordinate one, displaying the authors' decidedly hostile attitudes towards them. In contrast to this hostility, the participation of associations was highly valued, although, again, harbouring important differences. The various mediations of interests sketched out by Tatarin-Tarnheyden, Herrfahrdt, and Glum, respectively, defy conventional descriptions. Focusing on the difference between a pluralistic model of associations and an authoritarian corporatism, which is to say between societal and state corporatism ${ }^{13}-$ especially evident in older literature ${ }^{14}$ - the classification of state or authoritarian corporatism is obvious. But such categories are based on the existence of coercive associations that clearly contradict democratic principles. With regard to the authors considered here, one must remember that they based their theories on the model of the Imperial Economic Council, where principally representatives of free associations sat (Glum, 1930b, pp. 583-584). Moreover, they emphasize the essential role of free associations (Glum, 1925, p. 22, 1929, p. 35; Herrfahrdt, 1925$, p. 545,1932, p. 30$),{ }^{15}$ even though this is less pronounced in Tatarin-Tarnheyden's model of tiered representation bodies. What's more, coercive associations possess a noteworthy quality that is also constituent for democratic opinion formation: by involving all members of a group, they considerably broaden the constituency and thereby can claim a greater breadth of representation (Collin, 2011, p. 276).

(5) Finally, the concepts presented do not aim to concentrate power in the hands of a single leader. Notions such as "leader" (Führer) and "leadership" can be

\footnotetext{
10 See also Korioth (1990, p. 132); Otto (2002, pp. 74-76).

11 His repulsively anti-Semitic inclination becomes obvious in: Tatarin-Tarnheyden (1938), especially page 19, contra Kelsen and Heller.

12 For a similar argument regarding Tatarin-Tarnheyden, see Bohn (2011, pp. 73-74).

13 In particular, see Schmitter (1974, pp. 126-128).

14 For an overview, see Reutter (1991, pp. 177-179).

15 Presenting a contrary position that stresses a clear distinction between corporatist concepts and free associations, see Groh (2012, p. 41).
} 
found continuously in the literature, including the literature of democratic authors (Eitz, 2015, p. 121); however, this alone does not warrant the attribution of an "authoritarian principle" (Führerprinzip) or similar dictatorial ideas. There was surely an "authoritarian fad" at the end of the Weimar Republic, especially among corporatist authors (Beyer, 1941, p. 85; Meyer, 1997, pp. 247-249). However, this boost in popularity was manifested in various ways and not necessarily in the sense of blazing a path toward a dictatorship (Führerdiktatur). Glum's sympathies for fascist Italy (Glum, 1930a), which were really more aesthetically than politically motivated, do not indicate a commensurate prescription for Germany. His political machinations aiming at the creation of a united right-wing front (Weisbrod, 1995) did indeed include the temporary suspension of democratic principles, but not their complete abandonment. For TatarinTarnheyden, too, dictatorial mechanisms were at most transitional remedies (Tatarin-Tarnheyden, 1925/1926, p. 34). ${ }^{16}$ Herrfahrdt's principle of "arbitral leadership", which was to be implemented should corporatist mechanisms fail (Herrfahrdt, 1925, p. 546, 1932, p. 24), does not imply that power should be concentrated in the hands of a dictatorial strongman (Führer). Consequently, he has been criticized by national-socialists because the "Führer", from their perspective, was by no means a neutral arbitrator (Beyer, 1941, p. 83).

In contrast to Sontheimer's thesis (Sontheimer, 1964, pp. 200-201), corporatism and the authoritarian principle were not co-constitutive. And while national-socialism had no great affinity for corporatist concepts, ${ }^{17}$ corporatists did make overtures towards national-socialist ideology. ${ }^{18}$ It was above all Tatarin-Tarnheyden who tried to reconcile corporatism with the authoritarian principle (Tatarin-Tarnheyden, 1934, p. 28). However, this cannot be said to be the case prior to 1933. Finally, authoritarian thought substantially rebuffed democratic content, but it did not substitute this content with dictatorial concepts.

\section{Conclusion}

In the Weimar Republic, corporatist thought experienced renewed popularity. Some scholars of public law subscribed to this brand of thinking. Though a minority in the community of public law scholars, they were part of a broad trend in the contemporary debate.

The concepts developed by those scholars built on the institution of the Imperial Economic Council provided for in the Weimar Constitution as an organizational foundation. The idea contained therein to involve separate groups of social protagonists in lawmaking was developed in various ways. The corporatist authors aimed to strengthen societal self-regulation, on the one hand, while restraining parliamentary mechanisms, on the other.

These proposals, however, required justification. As the concepts went beyond the scope sketched out in the constitution, legitimation in terms of public law, even the most supreme law available was insufficient in this respect. Therefore, their focus was on legitimating considerations from the perspective of constitutional theory rather than from the perspective of constitutional law.

The considerations proceeded in two directions: Firstly, they intended to legitimize a significant modification concerning the organization of state lawmaking and, secondly, to justify strengthening societal self-regulation and the establishment of new forms of private-public co-regulation. On the input side, legitimation came from strengthening societal participation, and the more appropriate and effective realization of public interests was to satisfy the output criterion.

One central legitimation topos in these corporatist concepts was "democracy", which was closely linked to the notion of "self-administration". This was not only semantic camouflage. The notion of democracy in the Weimar period was very heterogeneous and remote from today's perspective. Understandings of democracy premised on minimum requirements for effective popular sovereignty, and considering contemporary circumstances, a number of substantial interfaces with democratic ideas appear, despite some distinctly authoritarian ideas about legitimation, in the corporatist concepts. They tried to address how power can be divided between the state and societal actors in a modern and functionally differentiated society. Thus, these concepts conceived of modes of mutual and self-determination in society while simultaneously paving the way for dictatorship by discrediting the parliamentary democracy.

\section{Acknowledgements}

This work was supported by the Cluster of Excellence "Normative Orders" (Frankfurt/Main) and the Max Planck Institute for European Legal History (Frankfurt/Main).

\section{Conflict of Interests}

The author declares no conflict of interests.

\section{References}

Albrecht, K. L. (1970). Hugo Sinzheimer in der Weimarer Nationalversammlung (Doctoral dissertation). Johann-Wolfgang-Goethe-Universität, Frankfurt am Main, Germany.

Anschütz, G. (1914). Deutsches Staatsrecht (7th ed.). Munich: C. H. Beck.

\footnotetext{
16 On the incompatibility of his concept with the "Führerprinzip", see also Meinck (1978, p. 97).

17 See in particular Benöhr (1999, pp. 153-154); Meinck (1978, p. 83).

18 On Glum, who was displaced after national-socialist hostilities and because of intrigues within the Kaiser Wilhelm Society: Przyrembel (2004, p. 12), Weisbrod (1995, pp. 306-305); on Herrfahrdt: Meinck (1978, pp. 101-102).
} 
Bähr, O. (1864). Der Rechtsstaat. Kassel: Wiegand.

Benöhr, S. (1999). Das faschistische Verfassungsrecht Italiens aus der Sicht von Gerhard Leibholz. BadenBaden: Nomos.

Beseler, G. (1843). Volksrecht und Juristenrecht. Leipzig: Weidmann.

Beyer, J. (1941). Die Ständeideologien der Systemzeit und ihre Überwindung. Darmstadt: L. C. Wittich.

Bohn, S. (2011). Die Idee vom deutschen Ständestaat. Ständische, berufsständische und korporative Konzepte zwischen 1918 und 1933. Hamburg: Diplomica Verlag.

Buddrus, M., \& Fritzlar, S. (2007). Die Professoren der Universität Rostock im Dritten Reich: Ein biographisches Lexikon. Munich: K. G. Saur.

Collin, P. (2011). Privatisierung und Etatisierung als komplementäre Gestaltungsprozesse. JuristenZeitung, 6, 274-282.

Collin, P. (2014). Konzeptionen, Spielarten und Wechselbeziehungen administrativer und justizieller Autonomie in Deutschland im späten 19. und frühen 20. Jahrhundert. Quaderni Fiorentini per la Storia del Pensiero Guiridico Moderno, 43, 165-228.

Collin, P. (2015). Regulierte Selbstregulierung der Wirtschaft. Neue Normierungsstrukturen im späten 19. und frühen 20. Jahrhundert. Zeitschrift für Neuere Rechtsgeschichte, 37, 10-31.

Collin, P. (2016). Privat-staatliche Regelungsstrukturen im frühen Industrie und Sozialstaat. Berlin: De Gruyter.

Eitz, T. (2015). Das Deutsche Reich ist eine Republik. In T. Eitz \& I. Engelhardt (Eds.), Diskursgeschichte der Weimarer Republik (pp. 100-151). Hildesheim: Olms.

Gassner, U. M. (1999). Heinrich Triepel: Leben und Werk. Berlin: Duncker \& Humblot.

Gehlen, B. (2013). Kommentar zu den Beiträgen von Mathias Schmoeckel und Ekkehart Reimer. In B. Gehlen \& F. Schorkopf (Eds.), Demokratie und Wirtschaft. Eine interdisziplinäre Herausforderung (pp. 143-149). Tübingen: Mohr Siebeck.

Gerber, H. (1932). Freiheit und Bindung der Staatsgewalt. Tübingen: Mohr Siebeck.

Gesch, K. (1926). Der Reichswirtschaftsrat. Untersuchung über seine Herkunft und seine Gestaltung (Doctoral dissertation). Friedrich-Alexander-Universität, Erlangen, Germany.

Gierke, O. (1873). Das deutsche Genossenschaftsrecht (Vol. 2). Berlin: Weidmann.

Gierke, O. (1902). Das Wesen der menschlichen Verbände. Berlin: Duncker \& Humblot.

Glum, F. (1920). Die Organisation der Riesenstadt. Die Verfassungen von Paris, London, New York, Wien und Berlin. Aus Anlaß des Entwurfs der Staatsregierung über die Bildung einer Stadt Groß-Berlin. Berlin: Springer.

Glum, F. (1925). Selbstverwaltung der Wirtschaft. Berlin: H. Sack.

Glum, F. (1929). Der deutsche und der französische Reichswirtschaftsrat. Ein Beitrag zu dem Problem der
Repräsentation der Wirtschaft im Staat. Berlin and Leipzig: De Gruyter.

Glum, F. (1930a). Das geheime Deutschland. Berlin: Stilke.

Glum, F. (1930b). Der Reichswirtschaftsrat. In G. Anschütz \& R. Thoma (Eds.), Handbuch des Deutschen Staatsrechts (pp. 578-585). Tübingen: Mohr.

Glum, F. (1931, October 22). Der Freiherr vom Stein und unsere Zeit. Lecture given at the 4th Technical Meeting of the Rhinland-Westphalian Coal Industry, Essen, Germany.

Groh, K. (2010). Demokratische Staatsrechtslehrer in der Weimarer Republik. Tübingen: Mohr Siebeck.

Groh, K. (2012). Gesellschaftliche Selbststeuerung? Verbändepluralismus und demokratische Staatsrechtslehre in der Weimarer Republik. In P. Collin, G. Bender, S. Ruppert, M. Seckelmann, \& M. Stolleis (Eds.), Regulierte Selbstregulierung im frühen Interventions- und Sozialstaat (pp. 33-52). Frankfurt am Main: Vittorio Klostermann.

Groh, K. (2014). Demokratiekonzepte führender deutscher Staatsrechtslehrer zu Beginn der Weimarer Republik. In H. Kämper, P. Haslinger, \& T. Raithel (Eds.), Demokratiegeschichte als ZäsurgeschichteDiskurse der frühen Weimarer Republik (pp. 237252). Berlin: De Gruyter.

Gusy, C. (2000). Fragen an das "demokratische Denken" in der Weimarer Zeit. In C. Gusy, (Ed.), Demokratisches Denken in der Weimarer Republik (pp. 635663). Baden-Baden: Nomos.

Herrfahrdt, H. (1921). Das Problem der berufsständischen Vertretung von der französischen Revolution bis zur Gegenwart. Stuttgart and Berlin: Deutsche Verlagsanstalt.

Herrfahrdt, H. (1922). Die Formen der wirtschaftlichen Selbstverwaltung in Deutschland. Jahrbuch des öffentlichen Rechts, XI, 1-37.

Herrfahrdt, H. (1925). Verwaltungsreform und berufsständische Bewegung. Die Tat, 17, 542-549.

Herrfahrdt, H. (1932). Der Aufbau des neuen Staates. Vorträge zur Verfassungsreform mit einem Plan für die Übergangsregelung in Reich und Preußen. Berlin: Verlag für Zeitkritik.

Huber, E. R. (1932). Die Berufsverbände und der Staat. Deutsches Volkstum, pp. 953-958.

Jerusalem, F. J. (1930). Gemeinschaft und Staat. Tübingen: Mohr Siebeck.

Jürgens, M. (2005). Staat und Reich bei Ernst Rudolf Huber. Frankfurt am Main: Peter Lang.

Klein, M. D. (2007). Demokratisches Denken bei Gustav Radbruch. Berlin: Berliner Wissenschafts-Verlag.

Korioth, S. (1990). Integration und Bundesstaat. Ein Beitrag zur Staats- und Verfassungslehre Rudolf Smends. Berlin: Duncker \& Humblot.

Kremer, C. (2012). Autonomie als Rechtsquelle: Die Diskussion über nicht-staatliche Rechtssetzungsbefugnisse in der Rechtssetzung des 19. Jahrhunderts. In P. Collin, G. Bender, S. Ruppert, M. Seckelmann, 
\& M. Stolleis (Eds.), Regulierte Selbstregulierung im frühen Interventions- und Sozialstaat (pp. 3-32). Frankfurt am Main: Vittorio Klostermann.

Kühne, J. (2000). Demokratisches Denken in der Weimarer Verfassungsdiskussion-Hugo Preuß und die Nationalversammlung. In C. Gusy (Ed.), Demokratisches Denken in der Weimarer Republik (pp. 115133). Baden-Baden: Nomos.

Lilla, J. (2012). Der Vorläufige Reichswirtschaftsrat 1920 bis 1933/34: Zusammensetzung-DokumentationBiographien. Düsseldorf: Droste.

Lobenstein-Reichmann, A. (2014). Der völkische Demokratiebegriff. In H. Heidrun Kämper, P. Haslinger, \& T. Raithel (Eds.), Demokratiegeschichte als Zäsurgeschichte-Diskurse der frühen Weimarer Republik (pp. 285-306). Berlin: De Gruyter.

Mayer-Tasch, P. C. (1971). Korporatismus und Autoritarismus. Eine Studie zu Theorie und Praxis der berufsständischen Rechts- und Staatsidee. Frankfurt am Main: Athenäum Verlag.

Meinck, J. (1978). Weimarer Staatslehre und Nationalsozialismus. Eine Studie zum Problem der Kontinuität im staatsrechtlichen Denken in Deutschland 1928 bis 1936. Frankfurt am Main and New York, NY: Campus.

Meyer, T. (1997). Stand und Klasse. Kontinuitätsgeschichte korporativer Staatskonzeptionen im deutschen Konservatismus. Opladen: Westdeutscher Verlag.

Moellendorff, W.v. (1916). Deutsche Gemeinwirtschaft. Berlin: Siegismund.

Moellendorff, W. v. (1919). Der Aufbau der Gemeinwirtschaft. Denkschrift des Reichswirtschaftsministeriums vom 7. Main 1919. Jena: Eugen Diederich.

Naphtali, F. (1928). Wirtschaftsdemokratie. Ihr Wesen, Weg und Ziel. Berlin: Verlagsgesellschaft d. Allg. dt. Gewerkschaftsbundes.

Nocken, U. (1981). Korporatistische Theorien und Strukturen in der deutschen Geschichte des 19. und frühen 20. Jahrhunderts. In U. v. Alemann (Ed.), Neokorporatismus (pp. 17-39). Frankfurt am Main and New York, NY: Campus.

Norpoth, M. (1998). Norm und Wirklichkeit. Staat und Verfassung im Werk Ernst Rudolf Hubers. Hamburg: Lit.

Otto, P. (2002). Die Entwicklung der Verfassungslehre in der Weimarer Republik. Frankfurt am Main: Peter Lang.

Pohl, T. (2002). Demokratisches Denken in der Weimarer Nationalversammlung. Hamburg: Verlag Dr. Kovač.

Przyrembel, A. (2004). Friedrich Glum und Ernst Telschow. Die Generalsekretäre der Kaiser-WilhelmGesellschaft: Handlungsfelder und Handlungsoptionen der "Verwaltenden" von Wissen während des Nationalsozialismus. Forschungsprogramm "Geschichte der Kaiser-Wilhlem-Gesellschaft im Nationalsozialismus". Ergebnisse 20. Berlin: Max-Planck-Gesellschaft zur Förderung der Wissenschaften.

Rehling, A. (2011). Konfliktstrategie und Konsenssuche in der Krise. Von der Zentralarbeitsgemeinschaft zur Konzertierten Aktion. Baden-Baden: Nomos Verlag.
Rehling, A. (2015). Demokratie und Korporatismus-eine Beziehungsgeschichte. In T. B. Müller \& A. Tooze (Eds.), Normalität und Fragilität. Demokratie nach dem Ersten Weltkrieg (pp. 133-153). Hamburg: Hamburger Edition.

Reutter, W. (1991). Korporatismustheorien. Frankfurt am Main: Peter Lang.

Riedel, H. (1991). Der Rätegedanke in den Anfängen der Weimarer Republik und seine Ausprägung in Art. 165 WRV. Frankfurt am Main: Peter Lang.

Ritter, G. A. (1994). Die Entstehung des Räteartikels 165 der Weimarer Reichsverfassung. Historische Zeitschrift, 258, 73-112.

Ritter, G. A. (1998). Politische Repräsentation durch Berufsstände. Konzepte und Realität in Deutschland 1871-1933. In W. Pyta \& L. Richter (Eds.), Gestaltungskraft des Politischen. Festschrift für Eberhard Kolb (pp. 261-280), Berlin: Duncker \& Humblot.

Rudischhauser, S. (2016). Geregelte Verhältnisse. Eine Geschichte des Tarifvertragsrechts in Deutschland und Frankreich (1890-1918/19). Cologne and Vienna: Böhlau.

Schmitter, P. C. (1974). Still the century of corporatism? The Review of Politics, 36, 85-131. doi:10.1017/S00 34670500022178

Schönberger, C. (2000). Elitenherrschaft für den sozialen Ausgleich: Richard Thomas "realistische" Demokratietheorie im Kontext der Weimarer Diskussion. In C. Gusy (Ed.), Demokratisches Denken in der Weimarer Republik (pp. 156-190). Baden-Baden: Nomos.

Schwinge, E. (1961). Heinrich Herrfahrdt. In E. Schwinge (Ed.), Festgabe für Heinrich Herrfahrdt zum 70. Geburtstag (pp. 1-3). Marburg: N. G. Elwert.

Sinzheimer, H. (1916). Ein Arbeitstarifgesetz. Die Idee der sozialen Selbstbestimmung im Recht. Munich and Leipzig: Duncker \& Humblot.

Smend, R. (1928). Verfassung und Verfassungsrecht. Munich and Leipzig: Duncker \& Humblot.

Sontheimer, K. (1964). Antidemokratisches Denken in der Weimarer Republik (2nd ed.). Munich: Nymphenburger Verlagshandlung.

Stolleis, M. (1999). Geschichte des öffentlichen Rechts in Deutschland (Vol. 3). Munich: C. H. Beck.

Tatarin-Tarnheyden, E. (1922). Die Berufsstände. Ihre Stellung im Staatsrecht und die Deutsche Wirtschaftsverfassung. Berlin: C. Heymann.

Tatarin-Tarnheyden, E. (1925/1926). Bolschewismus und Faschismus in ihrer staatsrechtlichen Bedeutung. Zeitschrift für die gesamte Staatswissenschaft 80 (1925/26), 1-37.

Tatarin-Tarnheyden, E. (1930). Berufsverbände und Wirtschaftsdemokratie. Ein Kommentar zu Art. 165 der Reichsverfassung. Berlin: Hobbing.

Tatarin-Tarnheyden, E. (1931). Volksstaat oder Parteienstaat. Rostock: Hinstorff.

Tatarin-Tarnheyden, E. (1934). Werdendes Staatsrecht. Berlin: C. Heymann.

Tatarin-Tarnheyden, E. (1938). Der Einfluß des Judentums 
in Staatsrecht und Staatslehre. Berlin: Deutscher Rechts-Verlag.

Triepel, H. (1928). Die Staatsverfassung und die politischen Parteien. Berlin: O. Liebmann.

Völtzer, F. (1992). Der Sozialstaatsgedanke in der Weimarer Reichsverfassung. Frankfurt am Main: Lang.

Walkenhaus, R. (1997). Konservatives Staatsdenken. Eine wissenssoziologische Studie zu Ernst Rudolf Huber. Berlin: De Gruyter.

Weisbrod, B. (1995). Das "Geheime Deutschland" und das "Geistige Bad Harzburg". Friedrich Glum und das Dilemma des demokratischen Konservatismus am Ende der Weimarer Republik. In C. Hansen, L. Niethammer, \& B. Weisbrod (Eds.), Von der Aufgabe der Freiheit. Politische Verantwortung und bürgerliche Gesellschaft im 19. und 20. Jahrhundert. Festschrift für Hans Mommsen zum 5. November 1995 (pp. 285-308). Berlin: Akademie Verlag.

Westphal, K. (1925). Der vorläufige Reichswirtschaftsrat im Gefüge der Reichsorganisation (Doctoral dissertation). Christian-Albrechts-Universität, Kiel, Germany.

\section{About the Author}

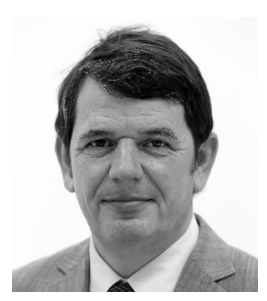

Peter Collin has been working at the Max Planck Institute for European Legal History since 2008. He was DFG-Fellow at the Graduate School for European Legal History in Frankfurt/Main from 1994 to 1997. From 1997 to 1999 he practised law; from 2000 to 2008 he was a research assistant at the University of Greifswald. There he obtained a post-doctoral qualification (Habilitation) in public law, modern legal and administrative history and science of public administration in 2008. 